\title{
Single institution experience of split course radiotherapy in patients with desmoid tumors
}

This article was published in the following Dove Medical Press journal: OncoTargets and Therapy

Jurui Luo $0^{1,2, *}$

Kairui Jin ${ }^{1,2, *}$

Shuizhang Qian ${ }^{1,2}$

Xuejun Ma ${ }^{1,2}$

Ziqiang $\operatorname{Pan}^{1,2}$

Weiqiang Yao ${ }^{1,2}$

Zhen Zhang ${ }^{1,2}$

Xiaomao Guo ${ }^{1,2}$

Xiaoli Yu ${ }^{1,2}$

'Department of Radiation Oncology, Fudan University Shanghai Cancer

Center, Shanghai 200032, China;

${ }^{2}$ Department of Oncology, Shanghai

Medical College, Fudan University,

Shanghai 200032, China

*These authors contributed equally to this work
Correspondence: Xiaoli Yu;

Xiaomao Guo

Department of Radiation Oncology,

Fudan University Shanghai Cancer

Center, 270 DongAn Road, Shanghai

200032, China

Tel +862164175590

Fax +86 21 64174774

Email stephanieyxl@hotmail.com;

guoxm1800@163.com
Purpose: This study aimed to assess the feasibility of split course radiotherapy (SCRT) and reports long-term outcomes in patients with desmoid tumors (DT).

Patients and methods: Between 2001 and 2004, 31 patients with recurrent $(n=19)$ or primary large desmoid fibromatosis $(\geq 10 \mathrm{~cm})(\mathrm{n}=12)$ who were treated with SCRT were retrospectively analyzed. All patients were treated with two phases of radiotherapy with a median interval time of 99 days (range: 81-122 days) and a median total dose of 6,399 cGy (range: 5,013-7,039 cGy). The median dose for the first phase was 3,969 cGy/22 Fx (range: 2,999-4,305 cGy), and 2,495 cGy/14 Fx (range: 1,982-3,039 cGy) for the second phase. Progression-free survival (PFS) in response to radiotherapy was evaluated using the Kaplan-Meier method and compared using the log-rank test. The prognostic factors associated with survival were evaluated by univariate and multivariate analyses.

Results: The median age of all patients was 30 years (range, 7-58 years). With a median follow-up of 60.4 months (range, 2-187 months), eight patients experienced disease progression after treatment. The PFS rate at 3 and 5 years for the whole population was $90 \%$ and $71.3 \%$, respectively. PFS for patients with split course of $<100$ days or $\geq 100$ days interval was $100 \%$ vs $78.6 \%$ at 3 years, and $80.4 \%$ vs $62.9 \%$ at 5 years, respectively ( $P=0.189$ ). In multivariate analysis, the radiotherapy (RT) interval time was an independent prognostic factor for PFS ( $\geq 100$ days vs $<100$ days, HR $11.544,95 \%$ CI 1.034-128.878, $P=0.047$ ). PFS was not significantly influenced by age, gender, surgery, tumor location, RT technology, or RT dose. Radiation-related acute complications occurred in nine (29\%) patients after RT, and RT-related long-term complications occurred in three $(9.7 \%)$ patients.

Conclusion: SCRT with an appropriate treatment interval ( $<100$ days) is well tolerated by DT patients with favorable long-term outcomes.

Keywords: split course radiation, desmoid tumors, local control

\section{Introduction}

Desmoid tumors (DT) are rare, benign tumors that arise in musculoaponeurotic tissues with a typical clinical behavior of infiltrative growth and frequent local recurrence and lack distant metastasis. ${ }^{1}$ The incidence of DT is five to six cases per 1 million people per year. ${ }^{2}$ Estrogen status, pregnancy, physical and surgical trauma, radiation, skeletal abnormalities, and genetic determinants are possible risk factors of DT, and $\sim 5 \%-10 \%$ of patient tumors arise in the context of familial adenomatous polyposis. ${ }^{3}$ Due to the rarity of this disease, there is no evidence from Phase III studies for the clinical management of DT, which is mainly based on many retrospective studies.

Surgery remains the mainstay of therapy for DT, but immediate surgery is not currently the standard treatment. Studies have shown that the progression-free survival (PFS) rates are $50 \%$ at 5 years for asymptomatic patients when they are managed 
with the front-line approach of watching and waiting, ${ }^{4-7}$ and $20 \%-30 \%$ of cases experience spontaneous regression. ${ }^{8}$ Hence, watchful waiting is considered a reasonable initial step for asymptomatic tumors, especially when surgery would involve a loss of function. ${ }^{3}$ In cases of locally advanced tumors, surgery remains the primary therapy. When surgery is used alone, local control rates are not favorable, varying from $32 \%$ to $84.6 \% .^{9-11}$ Tumor location, size, surgical margins, and patient age are all risk factors for local recurrence. ${ }^{12,13}$ Thus, adjuvant therapies, including radiotherapy (RT), chemotherapy, hormone, and anti-inflammatory therapy, or a combination regimen thereof, are applied in the treatment of DT. ${ }^{3}$ Sorafenib, a multi-targeted oral tyrosine kinase inhibitor, has become first-line treatment for advanced hepatocellular carcinoma. ${ }^{14,15}$ Gounder et al reviewed 26 patients with DT treated with sorafenib and 23/26 of them achieved disease control after a median treatment period of 6 months. ${ }^{16}$ An abstract from 2018 American Society of Clinical Oncology annual meeting reported a prospective randomized study comparing the effect of sorafenib and placebo in treating unresectable and progressive DT. The 1-year PFS for sorafenib and placebo were $87 \%$ and $43 \%$, respectively $(P<0.0001)$. These results might shed new light on the management of DT.

RT has also been used in patients after surgery or in those with unresectable tumors and recurrent tumors as well as in patients for whom resection would result in a loss of function. Postoperative RT has not been proven to convey a definite benefit after the first surgery, regardless of the resection margins. ${ }^{10,11}$ Some studies have reported that additional RT significantly improves the local control rate, while others failed to confirm the benefit of adjuvant RT.$^{9-11,17}$ In patients with incomplete surgical resection and those with recurrent tumors, RT can reduce the risk of recurrence. ${ }^{18-21}$ Due to the rarity of DT and limited studies regarding $\mathrm{RT}$, there are controversies with respect to dosing, timing, and indications for the treatment of DT. The purpose of split course radiotherapy (SCRT) is to add a break at midcourse of RT to facilitate repair of normal tissues and to decrease toxicity and improve RT tolerance. It has been practiced in various types of tumors. ${ }^{22-25}$ In this study, we report our institutional experience and long-term results of patients with DT who were treated with SRCT, comparing our results with previous studies with respect to RT in DT.

\section{Patients and methods Patients}

Between 2001 and 2004, 31 patients with refractory DT, either recurring from previous surgery $(n=19)$ or with a primary occurrence that is widely infiltrated with large bulk tumors (maximum dimension of the tumor $\geq 10 \mathrm{~cm}$ ) $(n=12)$, were included in this study. In the 12 patients with primary tumors, 4 patients suffered from pain caused by the tumors and 8 patients were considered as "progressed" after observation. DT diagnosis was pathologically confirmed for each case at Fudan University Shanghai Cancer Center. Fourteen patients with recurrent tumors and seven patients with large bulk tumors received palliative surgery. All patients received SCRT at our institution. Before treatment, all patients underwent a baseline assessment, including a physical examination, routine blood test, and appropriate imaging examination. After treatment, physical and imaging examination were applied to assess the tumor response. The treatment response was evaluated according to the RECIST criteria 1.1. Patients' clinical data were retrieved from medical records and telephone interviews with approval from the Institutional Review Board of Fudan University Shanghai Cancer Center. Confidentiality of patient data was maintained by the researchers and the study was conducted in accordance with the Declaration of Helsinki.

\section{Treatment}

With senior radiotherapists (Shuizhang Qian) who have experience treating DT working from 1960 onward, SCRT was developed as an in-house Institutional Review Boardapproved protocol for patients with refractory disease at Fudan University Shanghai Cancer Center. In this study, two phases of RT were applied to each patient to reduce toxicity to normal tissues, the planned dose for the first phase was 4,000 cGy/20 Fx and 2,000-2,400 cGy/10-12 Fx for the second phase. The interval between the two phases was designed to be 90-100 days to ensure that normal tissues had sufficient time to recover from acute toxicity. RT was delivered with megavoltage photons, including ${ }^{60} \mathrm{Co}(\mathrm{n}=4)$ at $6 \mathrm{MV}(\mathrm{n}=25)$ or $18 \mathrm{MV}(\mathrm{n}=2)$ in $1.8 \mathrm{~Gy}$ fractions (two patients received 1.9 Gy and another 1.5 Gy). Six patients (19.4\%) received three-dimensional conformal radiotherapy for gross disease; the other 25 patients $(80.6 \%)$ received conventional 2D RT. Tumors/scars were irradiated with an appropriate margin of 5-10 cm outside the tumor/scar in patients with tumors located in the extremities or long bones. In this case, attempts were made to avoid irradiation to joints as well as the entire circumference of extremities. Acute and longterm radiation-related complications were retrospectively scored using the Common Toxicity Criteria (CTC v3.0).

\section{Statistical analyses}

Disease progression was determined by assessing objective increases in size on radiographic studies and/or on 
the physical examination during physician follow-up. PFS was calculated from the last day of RT to the date of progress or last visit. Survival curves were created using the Kaplan-Meier method and compared using the log-rank test. Prognostic factors associated with PFS were evaluated with univariate and multivariate analyses with Cox regression. SPSS version 22 (IBM Corporation, Armonk, NY, USA) was used for statistical analysis. $P$-values $<0.05$ were considered significant (two-sided).

\section{Results}

\section{Patient characteristics and treatment}

From 2001 to 2004, 31 patients with recurrent or primary large DT were treated with SCRT, with a median follow-up time of 60.4 months (range, 2-187 months). The median patient age was 30 years (range, 7-58 years), and most patients were female $(64.5 \%)$. The patient characteristics are shown in Table 1. Nine tumors were located in the head/neck,

Table I Patients' characteristics and treatment

\begin{tabular}{l|l}
\hline Characteristics & Number of patients (\%) \\
\hline Age (years) & \\
Median (range) & $30(7-58)$ \\
$<30$ & $13(41.9 \%)$ \\
$\geq 30$ & $18(58.1 \%)$ \\
Gender & $20(64.5 \%)$ \\
Female & $11(35.5 \%)$ \\
Male & \\
Tumor size & $8(3-17 \mathrm{~cm})$ \\
Median (range) & $5(16.1 \%)$ \\
$<5$ cm & $16(51.6 \%)$ \\
$5-10$ cm & $10(32.3 \%)$ \\
$>10$ cm & \\
Location & $9(29.0 \%)$ \\
Head and neck & $10(32.3 \%)$ \\
Trunk & $12(38.7 \%)$ \\
Extremities & \\
Surgery & $21(67.7 \%)$ \\
Yes & $10(32.3 \%)$ \\
No & \\
RT technology & $25(80.6 \%)$ \\
$2 D$ & $6(19.4 \%)$ \\
$3 D-C R T$ & $6,399(5,013-7,039)$ \\
RT dose (cGy) & $6(19.4 \%)$ \\
Median (range) & $14(45.2 \%)$ \\
$\geq 5,000,<6,000 \mathrm{cGy}$ & $11(35.4 \%)$ \\
$\geq 6,000,<6,500 \mathrm{cGy}$ & \\
$\geq 6,500$ cGy & $99(81-122)$ \\
RT interval time & $17(54.8 \%)$ \\
Median (days) & $14(45.2 \%)$ \\
$<100$ days & \\
Total treatment time (days) & $150(129-168)$ \\
Median (range) &
\end{tabular}

Abbreviations: 3D-CRT, three-dimensional conformal radiotherapy; RT, radiotherapy
10 in the trunk, and 12 in the extremities. The median size of the maximal tumor dimension was $8 \mathrm{~cm}$, and $32.3 \%$ of patient tumors were $>10 \mathrm{~cm}$. Twenty-one patients received palliative surgery, while the remaining ten patients did not undergo surgery. Patients received a median total dose of 6,399 cGy/32 Fx (range: 5,013-7,039 cGy) split course irradiation. The median dose for the first phase was 3,969 cGy/22 Fx (range: 2,999-4,305 cGy), and for the second phase was 2,495 cGy/14 Fx (range: 1,982-3,039 cGy). The median treatment interval between the first and second phases was 99 days (range: $81-121$ days), and the median total treatment time was 150 days (range: 129-168 days).

\section{RT response and toxicity}

After the first phase of RT, partial response (PR) was seen in 3 patients $(9.7 \%)$ and 28 patients $(90.3 \%)$ had stable disease (SD). When the second phase was completed, 8 patients (25.8\%) had PR and the remaining 23 (74.2\%) had SD. During treatment, radiation-related acute complications occurred in nine $(29 \%)$ patients. Four patients developed moist desquamation, and two patients with abdominal tumors experienced radiation proctitis. Two patients experienced moderate edema in irradiated areas, and one patient with a neck DT experienced Grade II oral mucositis. RT-related long-term complications occurred in three $(9.7 \%)$ patients. Two patients with neck DT experienced brachial plexus injury, and one patient reported continuous pain in irradiated areas.

\section{Time to progression after RT}

With a median follow-up time of 60.4 months (range, 2-187 months), eight patients experienced progression after treatment for their current disease presentation. In four patients progression occurred inside the RT field, and in four patients it was outside the RT field. Five patients received re-salvage surgery, and one patient received re-irradiation after salvage surgery. The median time to progression was 42 months (range, 23.4-53 months). All progressed cases occurred within 5 years after RT. The actual PFS rates at 3 and 5 years were $90 \%$ and $71.3 \%$, respectively. Of 31 patients, $30(96.8 \%)$ were alive at the last follow-up and $1(3.2 \%)$ had died of severe anemia and malnutrition after 1 year of extensive colectomy and RT.

\section{Prognostic factor analysis}

The impacts of age, gender, tumor size, location, surgery, RT technology, RT dose, and interval time between the two phases on time to progression were analyzed using univariate and multivariate Cox regression models. In univariate 
Table 2 Univariate analysis of tumor and patient characteristics and PFS

\begin{tabular}{l|l|l|l}
\hline Variables & 3-year PFS (\%) & 5-year PFS (\%) & P-value \\
\hline $\begin{array}{l}\text { Age (years) } \\
<30\end{array}$ & 100 & & 0.729 \\
$\geq 30$ & 94.1 & 67.3 & \\
Gender & 100 & 76 & 0.885 \\
Male & 84.2 & 100 & \\
Female & & 72.6 & \\
Tumor size (cm) & 80 & & 0.048 \\
$<5$ & 92 & 40 & \\
$\geq 5$ & & 79 & \\
Location & 83.3 & 66.2 & \\
Head, neck, or trunk & 100 & 80.8 & \\
Extremities & & & \\
Surgery & 95.2 & 73.9 & \\
Yes & 77.8 & 66.7 & \\
No & & & \\
RT technology & 87.5 & 74.5 & \\
2D & 100 & 60 & \\
3D & & & \\
RT interval time \\
(days)
\end{tabular}

Abbreviations: PFS, progression-free survival; RT, radiotherapy.

analysis, age, gender, surgery, RT technology, and RT dose did not significantly impact disease progression $(P>0.5)$ (Table 2 ). The RT interval time ( $<100$ days or $\geq 100$ days) between the two phases tended to have an impact on disease progression. PFS for patients with $<100$ days or $\geq 100$ days of interval time was $100 \%$ vs $78.6 \%$ at 3 years, and $80.4 \%$ vs $62.9 \%$ at 5 years, respectively $(P=0.189)$ (Figure 1). Tumor size was also significantly associated with disease control, with 3- and 5-year PFS of $80 \%$ and $40 \%$ in

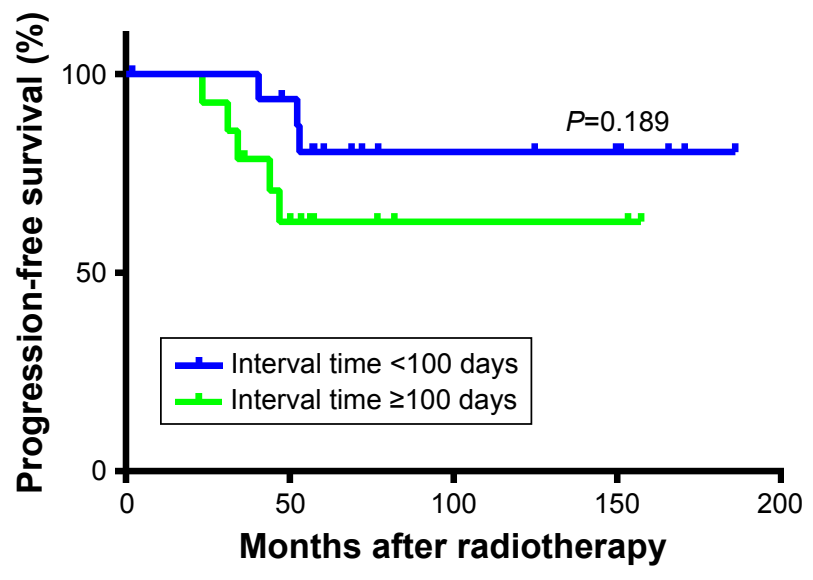

Figure I Progression-free survival curve for patients with a radiotherapy interval time $<100$ days (blue line) and $\geq 100$ days (green line). patients with $<5 \mathrm{~cm}$ tumors and $92 \%$ and $79 \%$ in patients with $\geq 5 \mathrm{~cm}$ tumors $(P=0.048)$, respectively. In multivariate analysis, tumor size ( $\geq 5 \mathrm{~cm}$ vs $<5 \mathrm{~cm}$, HR $0.052,95 \% \mathrm{CI}$ $0.005-0.602, P=0.018)$ and $\mathrm{RT}$ interval time ( $\geq 100$ days vs $<100$ day, HR 11.544 , 95\% CI 1.034-128.878, $P=0.047$ ) were independent prognostic factors for PFS (Table 3).

\section{Literature review}

To further investigate the value and indications of RT in DT management, we performed a literature review of major studies concerning the use of RT in treating DT. The results of the literature review are summarized in Table 4. ${ }^{9-11,17,26-37}$ When treated with surgery alone, the local control rate varied from $32 \%$ to $84.6 \% .^{9-11,17,26-32}$ For patients with positive surgical margins, the 6 -year local control rate was only $32 \%{ }^{11}$ When RT was combined with surgery in the management of DT, improved local control rates were observed by Jelinek et al (53\% treated with surgery alone vs $81 \%$ treated with surgery and RT, $P=0.018)$, Goy et al ( $32 \%$ vs $78 \%, P=0.02)$, and Baumert et al (62\% vs 93\%, $P=0.0028) .{ }^{10,11,28}$ On the other hand, several studies reported that patients treated with additional RT did not exhibit a significant benefit in local control., 17,27,29-32 Five studies including patients treated with RT alone showed favorable survival outcomes, with local control rates ranging from $75 \%$ to $92.3 \%$ and incidences of recurrence ranging from $24 \%$ to $29 \%$. $^{9,26,33,34}$

\section{Discussion}

This study presented the results of 31 patients treated with SCRT for refractory DT at a single institution. With a median total dose of 6,399 cGy/32 Fx irradiation, DT are effectively controlled with low incidence of side effects, and 3- and 5-year PFS of 90\% and 71.3\%, respectively.

Table 3 Multiple analyses for PFS with tumor and patient characteristics

\begin{tabular}{|c|c|c|c|}
\hline Variables & HR & $95 \% \mathrm{Cl}$ & P-value \\
\hline \multicolumn{4}{|l|}{ Age (years) } \\
\hline$\geq 30$ vs $<30$ & 0.351 & $0.048-2.568$ & 0.302 \\
\hline \multicolumn{4}{|l|}{ Tumor size (cm) } \\
\hline$\geq 5$ vs $<5$ & 0.052 & $0.005-0.602$ & 0.018 \\
\hline \multicolumn{4}{|l|}{ Location } \\
\hline $\begin{array}{l}\text { Extremities vs head, neck, or trunk } \\
\text { Surgery }\end{array}$ & 0.396 & $0.074-2.109$ & 0.278 \\
\hline Yes vs no & 1.029 & $0.176-6.011$ & 0.975 \\
\hline \multicolumn{4}{|l|}{ RT interval time (days) } \\
\hline$\geq 100$ vs $<100$ & I I.544 & $1.034-128.878$ & 0.047 \\
\hline \multicolumn{4}{|l|}{ RT dose (Gy) } \\
\hline$\geq 65$ vs $<65$ & 4.116 & $0.728-23.279$ & 0.109 \\
\hline
\end{tabular}

Abbreviations: PFS, progression-free survival; RT, radiotherapy. 
Table 4 Literature review of DT treatment and outcome

\begin{tabular}{|c|c|c|c|c|c|c|c|}
\hline \multirow[t]{2}{*}{ Study } & \multirow{2}{*}{$\begin{array}{l}\text { Number of } \\
\text { patients }\end{array}$} & \multirow{2}{*}{$\begin{array}{l}\text { Median } \\
\text { follow-up } \\
\text { time }\end{array}$} & \multirow{2}{*}{$\begin{array}{l}\text { Primaryl } \\
\text { recurrent } \\
\text { cases }\end{array}$} & \multicolumn{3}{|l|}{ Outcome (\%) } & \multirow[t]{2}{*}{$P$-value } \\
\hline & & & & Surgery & $\mathbf{R T}$ & Surgery + RT & \\
\hline $\begin{array}{l}\text { Gluck et al } \\
(201 \mathrm{I})^{9}\end{array}$ & 95 & 38 months & All primary & $\begin{array}{l}\text { Local control } \\
\text { rate: } 84.6\end{array}$ & $\begin{array}{l}\text { Local control } \\
\text { rate: } 92.3\end{array}$ & $\begin{array}{l}\text { Local control } \\
\text { rate: } 69.0\end{array}$ & 0.300 \\
\hline $\begin{array}{l}\text { Ballo et al } \\
(1999)^{26}\end{array}$ & 189 & 9.4 years & $\mathrm{N} / \mathrm{A}$ & $\begin{array}{l}\text { Incidence of } \\
\text { relapse: } 38\end{array}$ & $\begin{array}{l}\text { Incidence of } \\
\text { relapse: } 24\end{array}$ & $\begin{array}{l}\text { Incidence of } \\
\text { relapse: } 25\end{array}$ & - \\
\hline $\begin{array}{l}\text { Shin et al } \\
(2013)^{17}\end{array}$ & 119 & 6.8 years & $88 / 31$ & $\begin{array}{l}\text { Local control } \\
\text { rate: } 79.3\end{array}$ & - & $\begin{array}{l}\text { Local control } \\
\text { rate: } 60.2\end{array}$ & 0.776 \\
\hline $\begin{array}{l}\text { Jelinek et al } \\
(2001)^{10}\end{array}$ & 54 & 3.3 years & $33 / 21$ & Local control rate: 53 & - & Local control rate: $8 \mathrm{I}$ & 0.018 \\
\hline $\begin{array}{l}\text { Karabulut et al } \\
(2013)^{27}\end{array}$ & 21 & 4.4 years & N/A & $\begin{array}{l}\text { Median PFS: } \\
20.5 \text { months }\end{array}$ & - & $\begin{array}{l}\text { Median PFS: } \\
50 \text { months }\end{array}$ & $>0.05$ \\
\hline $\begin{array}{l}\text { Goy et al } \\
(1997)^{11}\end{array}$ & 56 & 6 years & $34 / 22$ & $\begin{array}{l}\text { Local control rate: } \\
32 \text { (margin }+)\end{array}$ & - & $\begin{array}{l}\text { Local control rate: } \\
78 \text { (margin+) }\end{array}$ & 0.02 \\
\hline $\begin{array}{l}\text { Baumert et al } \\
(2007)^{28}\end{array}$ & 110 & 6 years & N/A & Local control rate: 62 & - & Local control rate: 93 & 0.0028 \\
\hline $\begin{array}{l}\text { Pignatti et al } \\
(2000)^{29}\end{array}$ & 83 & 11.2 years & N/A & $\begin{array}{l}\text { Incidence of } \\
\text { recurrence: } 45.3\end{array}$ & - & $\begin{array}{l}\text { Incidence of } \\
\text { recurrence: } 41.2\end{array}$ & $>0.05$ \\
\hline $\begin{array}{l}\text { Guadagnolo } \\
\text { et al }(2008)^{30}\end{array}$ & 115 & 21 years & $46 / 69$ & Local control rate: 68 & & Local control rate: 75 & 0.12 \\
\hline $\begin{array}{l}\text { Zlotecki et al } \\
(2002)^{3 !}\end{array}$ & 72 & 6 years & $30 / 42$ & Local control rate: 82 & & Local control rate: 83 & 0.9038 \\
\hline $\begin{array}{l}\text { Ihalainen et al } \\
(2015)^{32}\end{array}$ & 121 & 7.5 years & $100 / 21$ & Local control rate: 70 & - & Local control rate: 63 & 0.564 \\
\hline $\begin{array}{l}\text { Sherman et al } \\
(1990)^{33}\end{array}$ & 45 & 7.6 years & N/A & - & $\begin{array}{l}\text { Incidence of } \\
\text { recurrence: } 29\end{array}$ & $\begin{array}{l}\text { Incidence of } \\
\text { recurrence: } 23\end{array}$ & - \\
\hline $\begin{array}{l}\text { Keus et al } \\
(2013)^{34}\end{array}$ & 44 & 4.8 years & $27 / 17$ & - & $\begin{array}{l}\text { Local control } \\
\text { rate: } 81.5\end{array}$ & - & - \\
\hline $\begin{array}{l}\text { Ergen et al } \\
(2016)^{35}\end{array}$ & 20 & 6.5 years & $4 / 16$ & - & - & Local control rate: 69 & - \\
\hline $\begin{array}{l}\text { Santti et al } \\
(2017)^{36}\end{array}$ & 41 & 7 years & N/A & - & $\begin{array}{l}\text { Local control } \\
\text { rate: } 75 \%\end{array}$ & - & \\
\hline $\begin{array}{l}\text { Kriz et al } \\
(2014)^{37}\end{array}$ & 52 & 3.7 years & $\mathrm{N} / \mathrm{A}$ & $\begin{array}{l}\text { Local control rate of } \\
\text { all patients: } 81 \%\end{array}$ & - & & \\
\hline
\end{tabular}

Abbreviations: DT, desmoid tumors; N/A, not available; PFS, progression-free survival; RT, radiotherapy.

To our knowledge, our study is the first report to address SCRT in DT.

DT are histologically benign neoplasms with locally aggressive behavior. The consensus for treatment is complete surgical resection. However, because of the infiltrative growth of DT and uncertain tumor margins, pursuing complete resection may result in a loss of function. Thus, it is not always possible to perform an extensive local excision. ${ }^{19,38}$ As shown in Table 4, the recurrence rates after surgery alone were high, and application of RT was reported to improve local control in several studies. ${ }^{10,11,28}$ A survival benefit was also observed in patients with positive surgical margins when RT was combined with surgery. ${ }^{11}$ Similar results were identified in a recently published meta-analysis of 1,295 patients with extra-abdominal DT, which concluded that microscopically positive margins exhibited a higher risk of recurrence and that RT appeared to reduce the risk but not for patients with negative margins. ${ }^{18}$ By contrast, other studies reported that postoperative RT had no definitive benefit on the recurrence rate but may delay tumor recurrence. ${ }^{9,17}$ In our study, 3- and 5 -year PFS for the entire population were $90 \%$ and $71.3 \%$, respectively, comparable to findings of other studies. ${ }^{35,37}$ Interestingly, the tumor control rate was not influenced by surgery in our study. The 5-year PFS rates were $73.9 \%$ for the 21 patients who received surgery plus RT and $66.7 \%$ for the 10 patients who received RT alone $(P=0.557)$. This result indicates that SCRT alone might be effective enough to provide significant local control for refractory DT. 
There are controversial results regarding a dose-response relationship when the RT dose is considered. A meta-analysis from Nuyttens et al reported a local control rate of $78 \%$ in response to 50-60 Gy $\mathrm{RT}^{21}$ Higher local control was observed with $>50$ Gy irradiation in other studies. ${ }^{28,35,36}$ A recently published study reported that the RT dose was significantly associated with local tumor control. The 5-year local control rate was $79 \%$ for patients who received $\geq 54$ Gy irradiation compared to $40 \%$ for patients who received $<54$ Gy $(P=0.023) .{ }^{35}$ Similar results were observed from Santti et al, ${ }^{36}$ who found that RT dose was the only factor with a significant impact on local tumor control. Doses of $<50$ Gy yielded a local control rate of $57 \%$, doses of 50-59.9 Gy yielded 75\%, and doses $\geq 60$ Gy reached $100 \%$. However, other studies failed to find a significant dose-response relationahip..$^{9,30,31}$ A prospective Phase II study from EORTC 62991-22998 reported that a dose of 56 Gy in 28 once-daily fractions provided adequate local control of $81.5 \%$ at 3 years for inoperable progressive DT with acceptable acute and late side effects. ${ }^{34}$ Our results are comparable with this study, with a 3-year local control rate of $90 \%$. However, in our study, a larger dose was delivered, with a median total dose of two phases of 6,399 cGy/32 Fx (range: 5,013-7,039 cGy). We did not observe that a higher RT dose was associated with better tumor control in our study. Instead, patients who received doses of $>65$ Gy $(n=11)$ tended to exhibit worse local control, with a 5-year PFS of $61.4 \%$ compared to $78.3 \%$ for patients who received $<65$ Gy irradiation $(n=20)(P=0.482)$. One possible reason for this result is that there were more patients $(54.4 \%)$ in the $\geq 65$ Gy group who exhibited larger $(\geq 10 \mathrm{~cm})$ and more aggressive tumors than $(35 \%)$ in the $<65$ Gy group, which may offset the efficacy of RT dose in tumor control.

Several prognostic factors, such as age, gender, tumor size, tumor location, and RT, in addition to surgery, have been associated with recurrence in previous studies. ${ }^{12}$ In our study, we found no association between recurrence after RT and age, gender, surgery, tumor location, RT technology, or RT dose in univariate and multivariate analyses. These conflicting results could be attributed to the limited sample size and different population. Patients with a larger tumor size have a higher risk of recurrence. ${ }^{12}$ However, we found that patients with $<5 \mathrm{~cm}$ tumors exhibited worse local control than patients with $\geq 5 \mathrm{~cm}$ tumors. The 5-year PFS rates of these two groups were $40 \%$ and $79 \%$, respectively $(P=0.048)$. Tumor size $(\geq 5 \mathrm{~cm}$ vs $<5 \mathrm{~cm}$ ) was also independently associated with PFS (HR 0.052, 95\% CI $0.005-0.602, P=0.018)$ in multivariate analysis. One reason for this result may be that only five patients in our study presented with tumors $<5 \mathrm{~cm}$. The limited sample size may have induced bias into our results. Another reason was that according to RECIST 1.1, progression was defined as the largest dimension of the tumor increased by at least $30 \%$ compared with previous dimension. Therefore, smaller tumors were more likely to be judged as progression because smaller growth would reach $30 \%$ of the previous dimension. PFS was also significantly influenced by the interval time between the two-phase irradiation treatments $(\geq 100$ days or $<100$ days). In univariate analysis, patients with an interval time $<100$ days tended to have more favorable outcomes compared to patients with $\geq 100$ days. The 5 -year PFS rates were $80.4 \%$ and $62.9 \%$, respectively, but the $P$-value was not statistically significant $(P=0.189)$. The interval time ( $\geq 100$ days vs $<100$ days) was an independent prognostic factor for PFS (HR 11.544, 95\% CI 1.034-128.878, $P=0.047$ ) in multiple analyses. SCRT is applied based on the radiobiology theory that normal tissue would repair during a break between treatments to decrease toxicity and improve tolerance to RT, which may facilitate higher doses of RT to the tumor without significantly increasing normal tissue toxicity. In 1989, a retrospective study reported a 30\% improvement in local control for nasopharynx cancer patients treated with a split course twice-a-day regimen compared with patients treated with conventional RT. ${ }^{39}$ Until now SCRT has been used for different cancers in clinical practice, such as prostate cancer, ${ }^{25}$ small cell lung cancer, ${ }^{24}$ head and neck cancer, ${ }^{23}$ colorectal cancer, and oligometastases, ${ }^{40}$ as well as in elderly and infirm patients, ${ }^{41}$ SCRT sometimes was accompanied by altered fractionation, with dose-fraction regimens which varied from $1.6 \mathrm{~Gy} / \mathrm{Fx}$, twice a day to $3.0 \mathrm{~Gy} / \mathrm{Fx}$, once a day. The split took place at the middle or latter part of the whole course. The durations of the break ranged from 14 to 40 days. ${ }^{22-24,42}$ To our knowledge, our study is the first to apply spilt course irradiation in DT. The results identified that the interval time was an important prognostic factor for local control. Although SCRT is designed to decrease RTinduced toxicity, caution is still warranted when deciding on suitable interval time, as longer interval times could weaken the efficacy of RT.

Generally, RT-induced toxicity is also an important issue. In our study, nine patients experienced acute toxicity. The most common acute toxicity was irradiation-related cutaneous reaction and mucositis, including desquamation (4/31), proctitis (2/31), and oral mucositis (1/31). Regarding tumor locations, acute toxicity incidence was 30\% (3/10) in patients with tumors located in extremities, $11.1 \%(1 / 9)$ 
in patients with tumors located in neck, and 50\% (5/10) in patients with tumors located in the trunk (intra-abdominal: 1/1, pelvic cavity: $1 / 1$, retroperitoneal tumor: $0 / 1$, chest wall: $1 / 3$, abdominal wall: $2 / 3$, back: $0 / 1$ ). So this treatment may be less toxic in patients with tumors in extremities or neck. Late toxicity was rarely observed (3/31), including long-term pain and radiation-related brachial plexus injury. However, the evaluation of late toxicity might be insufficient due to some patients being lost during follow-up.

\section{Limitations}

Our study has some drawbacks. First, the limitations of its retrospective nature and small simple size may induce some bias in our results. Second, the limited follow-up time may underscore an RT-induced late toxicity assessment. As DT are usually not life-threatening, quality of life in patients after treatment is imperative. We only observed three patients with RT-induced late toxicity in our study, which may have been insufficiently assessed. Third, many molecular predictors, such as $\beta$-catenin and $A P C$ mutation status, have been reported to be important for DT diagnosis and prognosis, ${ }^{43,44}$ which were not addressed in this study due to a lack of data on these parameters.

\section{Conclusion}

The present study observed that spilt course RT is an acceptable option for patients with recurrent or inoperable DT, as it is well tolerated and has favorable long-term local control. Less than a 100-day interval time seemed to be more effective in tumor control with acceptable RT-induced toxicity.

\section{Acknowledgments}

This work was partly supported by the National Natural Science Foundation of China (grant numbers: 81402525, 81372430, and 81602668), Shanghai Municipal Commission of Health and Family Planning Grant (grant number: 201440425), and the Shanghai Sailing Program (grant number: 16YF1401700). The abstract of this paper was presented at the 95th Scientific Assembly and Annual Meeting of Radiological Society of North America (December 2009, Chicago, IL, USA) as an oral presentation.

\section{Author contributions}

All authors contributed toward data analysis, drafting and revising the paper, gave final approval of the version to be published and agree to be accountable for all aspects of the work.

\section{Disclosure}

The authors report no conflicts of interest in this work.

\section{References}

1. Jo VY, Fletcher CD. WHO classification of soft tissue tumours: an update based on the 2013 (4th) edition. Pathology. 2014;46(2):95-104.

2. Penel N, Coindre JM, Bonvalot S, et al. Management of desmoid tumours: a nationwide survey of labelled reference centre networks in France. Eur J Cancer. 2016;58:90-96.

3. Kasper B, Baumgarten C, Garcia J, et al. An update on the management of sporadic desmoid-type fibromatosis: a European Consensus Initiative between Sarcoma PAtients EuroNet (SPAEN) and European Organization for Research and Treatment of Cancer (EORTC)/Soft Tissue and Bone Sarcoma Group (STBSG). Ann Oncol. 2017;28(10):2399-2408.

4. Lewis JJ, Boland PJ, Leung DH, Woodruff JM, Brennan MF. The enigma of desmoid tumors. Ann Surg. 1999;229(6):866-872.

5. Bonvalot S, Eldweny H, Haddad V, et al. Extra-abdominal primary fibromatosis: aggressive management could be avoided in a subgroup of patients. Eur J Surg Oncol. 2008;34(4):462-468.

6. Fiore M, Rimareix F, Mariani L, et al. Desmoid-type fibromatosis: a front-line conservative approach to select patients for surgical treatment. Ann Surg Oncol. 2009;16(9):2587-2593.

7. Briand S, Barbier O, Biau D, et al. Wait-and-see policy as a firstline management for extra-abdominal desmoid tumors. J Bone Joint Surg Am. 2014;96(8):631-638.

8. Colombo C, Miceli R, Le Péchoux C, et al. Sporadic extra abdominal wall desmoid-type fibromatosis: surgical resection can be safely limited to a minority of patients. Eur J Cancer. 2015;51(2):186-192.

9. Gluck I, Griffith KA, Biermann JS, Feng FY, Lucas DR, Ben-Josef E. Role of radiotherapy in the management of desmoid tumors. Int J Radia Oncol Biol Phy. 2011;80(3):787-792.

10. Jelinek JA, Stelzer KJ, Conrad E, et al. The efficacy of radiotherapy as postoperative treatment for desmoid tumors. Int J Radiat Oncol Biol Phys. 2001;50(1):121-125.

11. Goy BW, Lee SP, Eilber F, et al. The role of adjuvant radiotherapy in the treatment of resectable desmoid tumors. Int J Radiat Oncol Biol Phys. 1997;39(3):659-665.

12. Salas S, Dufresne A, Bui B, et al. Prognostic factors influencing progression-free survival determined from a series of sporadic desmoid tumors: a wait-and-see policy according to tumor presentation. J Clin Oncol. 2011;29(26):3553-3558.

13. Crago AM, Denton B, Salas S, et al. A prognostic nomogram for prediction of recurrence in desmoid fibromatosis. Ann Surg. 2013; 258(2):347-353.

14. Llovet JM, Ricci S, Mazzaferro V, et al; SHARP Investigators Study Group. Sorafenib in advanced hepatocellular carcinoma. $N$ Engl $J$ Med. 2008;359(4):378-390.

15. Cheng AL, Kang YK, Chen Z, et al. Efficacy and safety of sorafenib in patients in the Asia-Pacific region with advanced hepatocellular carcinoma: a phase III randomised, double-blind, placebo-controlled trial. Lancet Oncol. 2009;10(1):25-34.

16. Gounder MM, Lefkowitz RA, Keohan ML, et al. Activity of sorafenib against desmoid tumor/deep fibromatosis. Clin Cancer Res. 2011; 17(12):4082-4090.

17. Shin SH, Ko KR, Cho SK, Choi YL, Seo SW. Surgical outcome of desmoid tumors: adjuvant radiotherapy delayed the recurrence, but did not affect long-term outcomes. J Surg Oncol. 2013;108(1):28-33.

18. Janssen ML, van Broekhoven DL, Cates JM, et al. Meta-analysis of the influence of surgical margin and adjuvant radiotherapy on local recurrence after resection of sporadic desmoid-type fibromatosis. $\mathrm{Br} \mathrm{J}$ Surg. 2017;104(4):347-357.

19. Wood TJ, Quinn KM, Farrokhyar F, Dehehsi B, Corbett T, Ghert MA. Local control of extra-abdominal desmoid tumors: systematic review and meta-analysis. Rare Tumors. 2013;5(1):e2. 
20. Yao X, Corbett T, Gupta A, et al. A systematic review of active treatment options in patients with desmoid tumours. Curr Oncol. 2014;21(4): e613-e629.

21. Nuyttens JJ, Rust PF, Thomas CR, Turrisi AT. Surgery versus radiation therapy for patients with aggressive fibromatosis or desmoid tumors: a comparative review of 22 articles. Cancer. 2000;88(7):1517-1523.

22. Bledsoe TJ, Noble AR, Reddy CA, et al. Split-course accelerated Hypofractionated radiotherapy (SCAHRT): a safe and effective option for head and neck cancer in the elderly or infirm. Anticancer Res. 2016;36(3):933-939.

23. Daoud J, Toumi N, Siala W, Ghorbel A, Drira MM, Frikha M. Results of a prospective randomised trial comparing conventional radiotherapy to split course bifractionated radiation therapy in patients with nasopharyngeal carcinoma. Radiother Oncol. 2007;85(1):17-23.

24. Fukuda M, Nakamura Y, Kinoshita A, et al. Phase II study of irinotecan and cisplatin with concurrent split-course radiotherapy in limiteddisease small cell lung cancer. Cancer Chemother Pharmacol. 2012; 70(5):645-651.

25. Gogna NK, Baxi S, Hickey B, Baumann K, Burmeister E, Holt T. Splitcourse, high-dose palliative pelvic radiotherapy for locally progressive hormone-refractory prostate cancer. Int J Radiat Oncol Biol Phys. 2012; 83(2):e205-e211.

26. Ballo MT, Zagars GK, Pollack A, Pisters PW, Pollack RA. Desmoid tumor: prognostic factors and outcome after surgery, radiation therapy, or combined surgery and radiation therapy. J Clin Oncol. 1999; 17(1):158-167.

27. Karabulut S, Keskin S, Ekenel M, et al. The clinical effect of a positive surgical margin and adjuvant postoperative radiotherapy in the treatment of resectable desmoid tumors. Mol Clin Oncol. 2013;1(6): 1061-1064.

28. Baumert BG, Spahr MO, Von Hochstetter A, et al. The impact of radiotherapy in the treatment of desmoid tumours. An international survey of 110 patients. A study of the rare cancer network. Radiat Oncol. 2007; 2(1): 12 .

29. Pignatti G, Barbanti-Brodano G, Ferrari D. Extraabdominal desmoid tumor. A study of 83 cases. Clin Orthop Relat Res. 2000;375:207-213.

30. Guadagnolo BA, Zagars GK, Ballo MT. Long-term outcomes for desmoid tumors treated with radiation therapy. Int J Radiat Oncol Biol Phys. 2008;71(2):441-447.

31. Zlotecki RA, Scarborough MT, Morris CG, et al. External beam radiotherapy for primary and adjuvant management of aggressive fibromatosis. Int J Radiat Oncol Biol Phys. 2002;54(1):177-181.

32. Ihalainen HR, Koljonen V, Böhling TO, Tukiainen EJ, Sampo MM. The desmoid tumour: local control after surgical treatment. J Plast Surg Hand Surg. 2015;49(1):19-24.
33. Sherman NE, Romsdahl M, Evans H, Zagars G, Oswald MJ. Desmoid tumors: a 20-year radiotherapy experience. Int J Radiat Oncol Biol Phys. 1990;19(1):37-40.

34. Keus RB, Nout RA, Blay JY, et al. Results of a phase II pilot study of moderate dose radiotherapy for inoperable desmoid-type fibromatosis - an EORTC STBSG and ROG study (EORTC 62991-22998). Ann Oncol. 2013;24(10):2672-2676.

35. Ergen ŞA, Tiken EE, Öksüz DÇ, et al. The role of radiotherapy in the treatment of primary or recurrent desmoid tumors and long-term results. Balkan Med J. 2016;33(3):316-321.

36. Santti K, Beule AA, Tuomikoski L. Radiotherapy in desmoid tumors: treatment response, local control, and analysis of local failures. Strahlenther Onkol. 2017;193(4):269-275.

37. Kriz J, Eich HT, Haverkamp U, et al. Radiotherapy is effective for desmoid tumors (aggressive fibromatosis) - long-term results of a German multicenter study. Oncol Res Treat. 2014;37(5):4-260.

38. Pakos EE, Tsekeris PG, Goussia AC. Desmoid tumours of the extremities and trunk: a review of the literature. Int Orthop. 2005;29(4):210-213.

39. Luo RX, Tang QX, Huang YW, Liao YP, Mou XD, Hu ZX. Comparison of continuous and split-course radiotherapy for nasopharyngeal carcinoma. Int J Radiat Oncol Biol Phys. 1989;16(2):307-310.

40. Paik EK, Kim MS, Seo YS, et al. Feasibility of split-course stereotactic ablative radiotherapy for oligometastases. Jpn J Clin Oncol. 2018; 48(6):548-554.

41. Bledsoe TJ, Noble AR, Reddy CA, et al. Split-course accelerated Hypofractionated radiotherapy (SCAHRT): a safe and effective option for head and neck cancer in the elderly or infirm. Anticancer Res. 2016; 36(3):933-940.

42. Fu KK, Pajak TF, Trotti A, et al. A radiation therapy Oncology Group (RTOG) phase III randomized study to compare hyperfractionation and two variants of accelerated fractionation to standard fractionation radiotherapy for head and neck squamous cell carcinomas: first report of RTOG 9003. Int J Radiat Oncol Biol Phys. 2000;48(1):7-16.

43. Lips DJ, Barker N, Clevers H, Hennipman A. The role of APC and betacatenin in the aetiology of aggressive fibromatosis (desmoid tumors). Eur J Surg Oncol. 2009;35(1):3-10.

44. Kasper B, Gruenwald V, Reichardt P, Bauer S, Hohenberger P, Haller F. Correlation of CTNNB1 mutation status with progression arrest rate in RECIST progressive desmoid-type fibromatosis treated with imatinib: translational research results from a phase 2 study of the German interdisciplinary sarcoma Group (GISG-01). Ann Surg Oncol. 2016; 23(6):1924-1927.
OncoTargets and Therapy

\section{Publish your work in this journal}

OncoTargets and Therapy is an international, peer-reviewed, open access journal focusing on the pathological basis of all cancers, potential targets for therapy and treatment protocols employed to improve the management of cancer patients. The journal also focuses on the impact of management programs and new therapeutic agents and protocols on

\section{Dovepress}

patient perspectives such as quality of life, adherence and satisfaction The manuscript management system is completely online and includes a very quick and fair peer-review system, which is all easy to use. Visit http://www.dovepress.com/testimonials.php to read real quotes from published authors. 